\title{
Evaluation of the accuracy of parasitological techniques for the diagnosis of intestinal parasites in cats
}

\author{
Avaliaçáo da acurácia de técnicas parasitológicos para o diagnóstico de parasitos intestinais em gatos

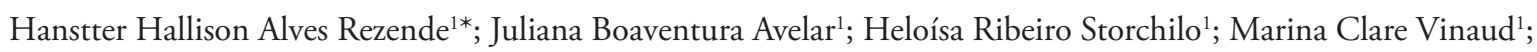 \\ Ana Maria de Castro ${ }^{1}$
}

\begin{abstract}
${ }^{1}$ Laboratório de Estudos da Relação Parasito-Hospedeiro - LAERPH, Instituto de Patologia Tropical e Saúde Pública, Universidade Federal de Goiás - UFG, Goiânia, GO, Brasil
\end{abstract}

Received February 12, 2015

Accepted April 27, 2015

\begin{abstract}
The accuracy of the parasitological techniques of Willis, Hoffman-Pons-Janer or Lutz (HPLJ), Sheather and Faust was evaluated in fecal samples from stray cats caught by the Zoonosis Control Center in Goiânia, Goiás, Brazil. These four techniques were applied separately to analyze $154 \mathrm{fecal}$ samples, and their accuracy was analyzed based on an evaluation of their sensitivity, specificity, positive and negative predictive values, and Kappa index, resulting in the selection of the Willis technique as the nominal gold standard. Of the 154 samples, 115 (74.68\%) tested positive for intestinal parasites. The analysis of the frequency of positivity indicated that the HPLJ technique detected $86.1 \%$ of the positive samples and was the closest to the gold standard. The analysis of the accuracy of the techniques was evaluated using the most prevalent parasites. The Sheather technique showed the highest accuracy in the detection of Ancylostomatidae, while the Sheather and HPLJ techniques showed similar accuracies in the detection of Cystoisospora spp. when compared to the gold standard. Lastly, the Faust technique showed the highest accuracy in the detection of Toxoplasma gondii when compared to the gold standard. This study underscores the importance of combining parasitological techniques in the diagnosis of intestinal parasites in cats.
\end{abstract}

Keywords: Accuracy, intestinal parasites, parasitological techniques, stray cats.

\section{Resumo}

A avaliação da acurácia das técnicas parasitológicas de Willis, Hoffman-Pons-Janer ou Lutz (HPJL), Sheather e Faust foram realizadas em amostras fecais de gatos capturados pelo Centro de Controle de Zoonoses em Goiânia, Goiás. Essas quatro técnicas foram utilizadas separadamente para análise de 154 amostras fecais. A análise de acurácia foi empregada, avaliando-se a sensibilidade, especificidade, valor preditivo positivo, valor preditivo negativo e índice kappa, sendo a técnica de Willis eleita como padrão-ouro. Das amostras analisadas 74,68\% (115/154) foram positivas para enteroparasitos. A análise de frequência de positividade demonstrou que a técnica HPJL detectou $86,1 \%$ dos positivos, aproximando-se do padrão-ouro. A avaliação da acurácia foi realizada pela análise dos parasitos mais prevalentes, sendo que, para Ancilostomídeos, a técnica de Sheather apresentou melhor acurácia; para Cystoisospora spp., as técnicas de Sheather e HPJL foram semelhantes e para Toxoplasma gondii, a técnica de Faust apresentou melhor acurácia comparada ao padráo ouro. Este estudo demonstra a importância da associaçáo de técnicas parasitológicas para o diagnóstico de enteroparasitos em gatos.

Palavras-chave: Acurácia, enteroparasitos, técnicas parasitológicas, gatos errantes.

\section{Introduction}

Cats play an important role in the transmission of zoonotic agents, especially of heteroxenous parasites that may infect humans, leading to important public health diseases such as cutaneous larva migrans, visceral larva migrans, toxoplasmosis, giardiasis and

${ }^{*}$ Corresponding author: Hanstter Hallison Alves Rezende. Tropical Pathology and Public Health Institute, Universidade Federal de Goiás - UFG, Rua 235,

s/n, Setor Universitário, CEP 74650-050, Goiânia, GO, Brasil.

e-mail: hanstter.bio@hotmail.com cryptosporidiosis, among others (SCHANTZ, 1991; MCCARTHY \& MOORE, 2000; SERRA et al., 2003). Several diagnostic techniques have been used in order to identify the different parasite stages, thus providing a more reliable diagnosis. The techniques most commonly employed are: zinc sulfate centrifugal flotation (Faust), flotation in saturated sodium chloride solution (Willis), spontaneous sedimentation (Hoffman-Pons-Janer-Lutz), and the formol ether concentration technique (DE CARLI, 2001; 
DE CARLI \& OLIVEIRA, 2001; MARIANO et al., 2005; MACHADO et al., 2008).

Numerous clinical and veterinary diagnostic laboratories seek a parasitological methodology that combines specificity, sensitivity, speed and low operational cost. A correctly performed parasitology stool test enables the identification of the etiological agent responsible for the disease, the parasite burden, effective treatment and follow-up. It can also be used in epidemiological surveys as a guideline for the adoption of local prophylactic measures, and as an indication of the quality of population health. Therefore, this test is an extremely important component of human and veterinary medicine practices (VAZ, 2001; MENDES et al., 2005; TOSATO et al., 2005; MACHADO et al., 2008).

The parasitological method most routinely employed is the Hoffman-Pons-Janer or Lutz (HPJL) technique, which has the advantage of requiring minimal materials and financial resources, but the disadvantage of involving large amounts of fecal debris from each sample, which hinders the microscopic analysis of the material. Hence, combining different parasitological techniques is useful for the correct identification of different species of parasites and improves the diagnostic accuracy (FLANAGAN, 1992; TASCA, 2001).

The purpose of this study was to assess the accuracy of different parasitological stool test methods for the detection of intestinal parasites, with emphasis on the detection of T. gondii oocysts.

\section{Materials and Methods}

\section{Study}

This study was approved by the Animal Ethics Committee (CEUA) of the Federal University of Goiás, under Protocol no. 054/2013).

One hundred and fifty-four fecal samples were obtained from stray cats captured by the Zoonosis Control Center of Goiânia, GO. The samples were placed in sterile universal fecal collectors and refrigerated until processing at the Laboratory of Host-Parasite Relationship Studies (LAERPH) of the Institute of Tropical Pathology and Public Health at the Federal University of Goiás.

\section{Analysis of samples}

Various parasitological techniques were employed to identify cysts and oocysts of protozoan parasites, eggs and larvae of parasitic helminths in the feces of stray cats. These techniques were flotation in a saturated sucrose solution, density $1.2 \mathrm{~g} / \mathrm{mL}$ (SHEATHER, 1923), spontaneous sedimentation (HOFFMAN et al., 1934; LUTZ, 1919), zinc sulfate centrifugal flotation density $1.18 \mathrm{~g} / \mathrm{mL}$ (FAUST et al., 1938), and flotation in saturated sodium chloride solution density $1.2 \mathrm{~g} / \mathrm{mL}$ (WILLIS, 1921). The Willis technique was elected as the gold standard in this study due to its ability to detect helminth eggs and larvae and coccidian oocysts, especially T. gondii oocysts.

\section{Statistical analysis}

The prevalence of intestinal parasites, the frequency of positivity for each parasite and for each technique were evaluated. To evaluate the diagnostic tests, the sensitivity, specificity, positive predictive value (PPV), negative predictive value (NPV), and Kappa index $(\mathrm{K})$ of each technique were compared with the gold standard (Willis technique). The parasitological results were analyzed using Epi Info 3.2.1 software (CDC, 2015).

\section{Results and Discussion}

Among the 154 analyzed fecal samples, 74.68\% (115/154) were positive for intestinal parasites (Table 1).

Associations were observad between Ancylostomatidae and T. gondii (8 cases), Ancylostomatidae and Cystoisospora sp. (23 cases), T. gondii and Cystoisospora sp. (4 cases), Ancylostomatidae, T. gondii and Cystoisospora sp. (5 cases), Ancylostomatidae, Cystoisospora sp. and Giardia sp. (1 case) and Ancylostomatidae, Cystoisospora sp. and T. cati (1 case).

The frequency of positivity of each technique was analyzed, based on the 115 positive samples. The Willis technique detected $97.4 \%(112 / 115)$ of the positive samples and presented three false negative results. The HPLJ technique detected 86.1\% (99/115) of the positive samples and was the closest to the gold standard, followed by the Sheather technique, which detected $79.1 \%$ $(91 / 115)$. The technique with the lowest frequency of positivity was Faust, with 73\% (84/115). Even the gold standard was not able to detect $100 \%$ of the positive samples, which reinforces the need to use more than one diagnostic technique. The association of various diagnostic techniques with different principles favors the identification of a greater number of parasitic structures, thus increasing the diagnostic efficacy (SANTOS \& CASTRO, 2006). This study confirmed that using a combination of the gold standard technique (Willis) and the HPJL method, which is the technique most widely employed in diagnostic laboratories, increases the diagnostic efficiency.

The accuracy of the techniques was analyzed based on the parasites that showed the highest frequency, i.e., Ancylostomatidae, Cystoisospora sp. and T. gondii. Thus, in the detection of Ancylostomatidae eggs, the accuracy of the HPLJ, Faust and Sheather techniques was analyzed in comparison to that of the Willis technique (gold standard). This analysis revealed that the Sheather technique presented the highest accuracy, showing

Table 1. Frequency of intestinal parasites in fecal samples from stray cats captured by the Center of Control of Zoonosis, in the year of 2012, from Goiania, Goiás, Brazil.

\begin{tabular}{cccc}
\hline Parasite & N & \% & IC 95\% \\
\hline Ancylostomatidae & 58 & 62.3 & $53.9-70.1$ \\
Cystoisospora spp. & 9 & 27.9 & $8.4-19.5$ \\
Giardia sp. & 2 & 1.3 & $20.8-35.1$ \\
Toxocara cati & 2 & 1.3 & $0-3.2$ \\
Toxoplasma gondii & 21 & 13.6 & $0-3.2$ \\
\hline
\end{tabular}


$81.1 \%$ of sensitivity and $98.4 \%$ of specificity, a PPV of $98.6 \%$ and NPV of $78.8 \%$, and a $k$ index in good agreement with that of the gold standard (Table 2).

Cerqueira et al. (2007) compared the efficiency of the Willis technique to that of the HPLJ method and found that the latter was more sensitive for the diagnosis of Ancylostomatidae. In our study, the HPLJ technique showed good agreement with the gold standard, with $k=0.689$. However, the accuracy of the Sheather technique was higher than that of the HPLJ technique for the diagnosis of Ancylostomatidae, because these parasites have light eggs that are more easily detected by flotation with density differences of the Sheather technique (SHEATHER, 1923; DE CARLI, 2001). The use of flotation techniques enables the separation of fecal debris from parasitic structures, the use of Sheather solution with a density of $1.2 \mathrm{~g} / \mathrm{ml}$ promotes the flotation of the eggs which present density ranging from 1.023 to 1.050 (DAVID \& LINDQUIST, 1982).

The Faust technique showed the lowest sensitivity (73\%) and lowest $k$ index $=0.667$. This sensitivity finding differs from that found in the study of Souza-Dantas et al. (2007), who reported a sensitivity of $100 \%$ when compared with the necropsy of the intestinal tract of cats.

In the analysis of the accuracy of the diagnosis of Cystoisospora sp. oocysts, the HPLJ and Sheather techniques showed the same results, both with $66.7 \%$ of sensitivity, $97.4 \%$ of specificity, PPV of $89.7 \%$, NPV of $89.6 \%$ and a $k$ index of 0.700 , which were in good agreement with the gold standard (Table 3 ).
For the diagnosis of Coccidia, flotation techniques using hypertonic solutions are recommended. Our results reinforce those of studies that demonstrate the accuracy achieved by associating the Willis and Sheather techniques, or even the HPLJ and Willis or Sheather techniques in routine laboratory tests (GARCIA et al., 1995; GARCIA, 2007).

The accuracy of the results of the detection of $T$. gondii oocysts showed that the Faust technique presented the highest sensitivity (66.7\%), specificity (99.3\%), PPV (92.3\%), NPV (95.7\%) and $\mathrm{k}$ index, in agreement with the gold standard (Table 4).

In this analysis, the three techniques showed sensitivities lower than $70 \%$. Flotation in saturated solutions is recommended for oocysts and offers good diagnostic sensitivity (SHEATHER, 1923; FAUST et al., 1938; DRYDEN et al., 2005). Therefore, for the diagnosis of $T$. gondii oocysts, it is advisable to use a combination of the Willis and Faust techniques or the Willis and Sheather techniques, in which the $k$ index was 0.627 , representing a good agreement.

In conclusion, this study demonstrated that the combined use of parasitological techniques is important for the diagnosis of intestinal parasites in cats. The association of the Sheather and Willis techniques showed higher accuracy in the diagnosis of Ancylostomatidae and Cystoisospora sp., while the Faust technique in association with the Willis technique (gold standard) showed higher accuracy in the diagnosis of $T$. gondii.

Table 2. Evaluation of the accuracy of the Sheather, Faust and Hoffman-Pons-Janer-Lutz techniques compared to the Willis technique (golden standard), for the diagnosis of Ancylostomatidae.

\begin{tabular}{cccccc}
\hline & Sensitivity $\%$ & Specificity $\%$ & PPV $\%$ & NPV \% & Kappa index \% \\
\hline Sheather & 81.1 & 98.4 & 98.6 & 78.8 & 72.1 \\
Faust & 73 & 96.9 & 97 & 768 & 0.667 \\
HPJL & 78.9 & 92.2 & 93.4 & 75.6 & 0.689 \\
\hline
\end{tabular}

PPV: positive predictive value; NPV: negative predictive value; HPJL: Hoffman-Pons-Janer-Lutz.

Table 3. Evaluation of the accuracy of the Sheather, Faust and Hoffman-Pons-Janer-Lutz techniques in comparison to the Willis technique (golden standard), for the Cystoisospora sp. diagnosis.

\begin{tabular}{cccccc}
\hline & Sensitivity \% & Specificity \% & PPV \% & NPV \% & Kappa index \% \\
\hline Sheather & 66.7 & 97.4 & 89.7 & 89.6 & 0.700 \\
Faust & 53.8 & 97.4 & 87.5 & 86.2 & 0.587 \\
HPJL & 66.7 & 97.4 & 89.7 & 89.6 & 0.700 \\
\hline
\end{tabular}

PPV: positive predictive value; NPV: negative predictive value; HPJL: Hoffman-Pons-Janer-Lutz; $k$ : kappa index.

Table 4. Evaluation of the accuracy of the Sheather, Faust and Hoffman-Pons-Janer-Lutz techniques in comparison to the Willis technique (golden standard), for the Toxoplasma gondii diagnosis.

\begin{tabular}{cccccc}
\hline & Sensitivity \% & Specificity \% & PPV \% & NPV \% & Kappa index \% \\
\hline Sheater & 61.1 & 97.1 & 73.3 & 95 & 0.627 \\
Faust & $\mathbf{6 6 . 7}$ & $\mathbf{9 9 . 3}$ & $\mathbf{9 2 . 3}$ & $\mathbf{9 5 . 7}$ & $\mathbf{0 . 7 5 0}$ \\
HPJL & 55.6 & 98.5 & 83.3 & 94.4 & 0.632 \\
\hline
\end{tabular}

PPV: positive predictive value; NPV: negative predictive value; HPJL: Hoffman-Pons-Janer-Lutz; $k$ : kappa index. 


\section{References}

Centers for Disease Control and Prevention - CDC. Epi Info [online]. Atlanta: CDC; 2015 [cited 2015 Feb 12]. Available from: http://wwwn. cdc.gov/epiinfo/

Cerqueira EJL, Arcanjo MS, Alcântara LM. Análise comparativa da sensibilidade da técnica de Willis, no diagnóstico parasitológico da Ancilostomíase. Diálogos de Ciência 2007; 5: 1-7.

David ED, Lindquist WD. Determination of the specific gravity of certain helminth eggs using sucrose density gradient centrifugation. J Parasitol 1982; 68(5): 916-919. http://dx.doi.org/10.2307/3281005. PMid:6890102.

De Carli GA, Oliveira OLM. Controle de qualidade em parasitologia clínica. In: De Carli GA. Parasitologia clínica: seleção de métodos e técnicas de laboratório para o diagnóstico das parasitoses humanas. São Paulo: Editora Atheneu; 2001. p. 577-610.

De Carli GA. Colheita e preservação da amostra fecal. In: De Carli GA. Parasitologia clínica: seleção de métodos e técnicas de laboratório para o diagnóstico das parasitoses humanas. São Paulo: Editora Atheneu; 2001. p. 3-26.

Dryden MW, Payne PA, Ridley R, Smith V. Comparison of common fecal flotation techniques for the recovery of parasite eggs and oocysts. Vet Ther 2005; 6(1): 15-28. PMid:15906267.

Faust EC, D’Antoni JS, Odom V, Miller MJ, Peres C, Sawitz W, et al. A critical study of clinical laboratory technics for the diagnosis of protozoan cysts and helminth eggs in feces. Am J Trop Med Hyg 1938; 18(2): 169-183.

Flanagan PA. Giardia - diagnosis, clinical course and epidemiology. A review. Epidemiol Infect 1992; 109(1): 1-22. PMid:1499664.

Garcia LS, Bullock-Iacullo S, Palmer J, Shimizu RY. Diagnosis of parasitic infections: collection, processing, and examination of specimens. In: Murray PR, Baron EJ, Pfaller MA, Tenover FC, Yolken RH, editors. Manual of clinical microbiology. Washington: ASM Press; 1995. p. 2674-2698.

Garcia LS. Diagnostic medical parasitology. 5th ed. Washington: ASM Press; 2007.

Hoffman WA, Pons JA, Janer JL. The sedimentation concentration method in schistosomiasis mansoni. PR J Public Health Trop Med 1934; 9: 283-291.

Lutz AOO. Schistosoma mansoni e a schistosomatose segundo observações, feitas no Brazil. Mem Inst Oswaldo Cruz 1919; 11(1): 121-155. http:// dx.doi.org/10.1590/S0074-02761919000100006.

Machado ER, Santos DS, Costa-Cruz JM. Enteroparasites and commensal among children in four peripheral districts of Uberlândia, State of Minas
Gerais. Rev Soc Bras Med Trop 2008; 41(6): 581-585. http://dx.doi. org/10.1590/S0037-86822008000600007. PMid:19142436.

Mariano MLM, Carvalho SMS, Mariano APM, Assunção FR, Carzola IM. Uma nova opção para diagnóstico parasitológico: Método de Mariano e Carvalho. NewsLab 2005; 68: 132-140.

McCarthy J, Moore TA. Emerging helminth zoonoses. Int J Parasitol 2000; 30(12-13): 1351-1360. http://dx.doi.org/10.1016/S00207519(00)00122-3. PMid:11113260.

Mendes CR, Teixeira ATLS, Pereira RAT, Dias LCS. Estudo comparativo entre os métodos de Kato-Kazt e coprotest. Rev Soc Bras Med Trop 2005; 38(2): 178-180. http://dx.doi.org/10.1590/S0037-86822005000200010. PMid:15821795.

Santos SV, Castro JM. Ocorrência de agentes parasitários com potencial zoonótico de transmissão em fezes de cães domiciliados no município de Guarulhos, SP. Rev Arq Inst Biol 2006; 73(2): 255-257.

Schantz PM. Parasitic zoonoses in perspective. Int J Parasitol 1991; 21(2): 161-170. http://dx.doi.org/10.1016/0020-7519(91)90006-S. PMid:1869350.

Serra CMB, Uchôa CMA, Coimbra RA. Exame parasitológico de fezes de gatos (Felis catus domesticus) domiciliados e errantes da Região Metropolitana do Rio de Janeiro, Brasil. Rev Soc Bras Med Trop 2003; 36(3): 331-334. http://dx.doi.org/10.1590/S0037-86822003000300003. PMid:12908032.

Sheather AL. The detection of intestinal protozoa and mange parasites by a floatation technique. J Comp Pathol Ther 1923; 36: 266-275. http:// dx.doi.org/10.1016/S0368-1742(23)80052-2.

Souza-Dantas LM, Bastos OPM, Brener B, Salomão M, Guerrero J, Labarthe NV. Técnica de centrífugo-flutuação com sulfato de zinco no diagnóstico de helmintos gastrintestinais de gatos domésticos. Cienc Rural 2007; 37(3): 904-906. http://dx.doi.org/10.1590/S0103-84782007000300051.

Tasca T. Incidência de enteroparasitos na cidade mais fria do Brasil: São José dos Ausentes, Rio Grande do Sul. Rev Brasil Anal Clin 2001; 33(1): 10-20.

Tosato MEVB, Pilonetto M, Scarin AK. Apuração de custos para a realização de urocultura em um laboratório de médio porte do setor privado. NewsLab 2005; 12(69): 114-142.

Vaz AJ. Diagnóstico imunológico das parasitoses. In: De Carli AG. Parasitologia clinica: seleção de métodos e técnicas de laboratório para o diagnóstico das parasitoses humanas. São Paulo: Editora Atheneu; 2001. p. 505-540.

Willis HHA. A simple levitation method for the detection of hookworm ova. Med J Aust 1921; 8: 375-376. 